\title{
Role of Football in International Business and Economy
}

\author{
Erdenedalai Batmunkh ${ }^{1, *}$ \\ ${ }^{1}$ Binjiang College of Nanjing University of Information Science and Technology, Wuxi, China \\ ${ }^{*}$ Corresponding author: batmonh64@gmail.com
}

Received June 6 2021; Revised June 20 2021; Accepted June 212021

\begin{abstract}
Football events are one of the most significant sports events globally while football is one of the most popular sports. Thus, the football industry and football-related businesses plays an important role in trade and economy. In the current study key events and top associations and organizations of the football industry are identified, and their role beyond playing grounds is observed. Also, the role the football industry plays in the economic and financial developments of nations, brands and organizations and individuals is highlighted. A comprehensive chart has been drawn that presents a comprehensive structure of the global football industry and also identifies key sources of revenue and expenditures. The study is important for scholars interested in sports economics and sustainable economic development through sports.
\end{abstract}

Keywords: Football; Sports Economics; International Trade; FIFA; World Cup

\section{Introduction}

Some countries have oil or rare earth, while others have sports. Natural resources do play an important role innations' socio-economic development however, scarcity of natural resources does not prevent us from looking to other avenues for revenue. Sport is one such avenue for many nations in the world. Sport, though it is a source of health and peace, is also a stimulus for many economies and organizations. Approximating sports' economic value to the world trade and economy is difficult, but if one looks at the fact that European countries have imported sporting goods equal to $€ 13.3 \mathrm{~B}$ and exported around $€ 11.7 \mathrm{~B}$ in 2019 (Eurostat, 2021), it is not difficult to visualize the size of the sports industry.

What is the most popular sport? Many argue that it is football. Football is also called soccer in some countries, such as the United States of America. The Fédération Internationale de Football Association (FIFA) was founded in 1904 in Paris with only 7 European authorities, and today is the most well-known face of the football industry (Simon et al., 2019). Today, the association has 211 member associations in it. Also, there were 250 million active footballers worldwide (FIFA, 2001). Thus, there is no wonder in the fact that the football world cup is the most-watched tournament in the world. Football World Cup 2018, held in Russia, had 3.57 Billion viewers around the globe (FIFA, 2018c).

Football in many ways contributes to international business, trade, and economy. For instance, the production of sports products, ticket sales, salaries of football players, broadcasting rights are 
just a few dimensions of football economics. Globalization is deeply associated with football in many ways, from international players to international organizations. However, the literature review suggested that despite the importance of the football industry for an economy and population, a comprehensive study of the global football industry's role in international trade and economy has rarely been studied. To fill this gap, the current study was undertaken.

The current study will study the football industry at different levels, clubs, leagues and tournaments, associations, brands, and broadcasting. Each of them is significant in the modern football industry and has a distinct role to play. The study will start from the team-level football industry (clubs and national teams) then will study the business of the leagues and associations. Finally, a bigger picture will be presented.

The rest of the study is organized as follows. The second section presents an overview of the football industry. In this section the business of the professional football industry is explained with examples, starting from the football clubs. The third section presents how the football industry serves a nation in light of nations' socio-economic development. In the third section, one of the biggest international football development programs is explained from an economic perspective. Lastly, the study is concluded with important insights and implications.

\section{Overview of Football Industry}

Football was a product of transnational connections and free trade (Lanfranchi \& Taylor, 2001). Mendoza (2017) argued that a country's GDP per capita and Human Development Index both are highly dependent on FIFA ranking. Gásquez and Royuela (2014) suggested that in the absence of complete information, FIFA ranking can complement our understanding of the development in those countries. For instance, Japan, Qatar, and China lead Asian football in many ways (FIFA, 2021c), and they are all wealthy countries.

The football industry is a Billion Dollar industry that creates facilities, workplaces and brands. One main concept is that organizations can create clubs while the associations usually collect players for the national team. From fan watching a match to player transferring are all business. Overall, European football was the role model for other countries' football development. However, some other continent nations are in the process of building their giant industry such as Japan and China. The J1 League of Japan was founded in 1992 by Japan's football association, and they plan to become a world champion (Manzenreiter \& Horne, 2018, pp. 639-657). Besides, football fans in China have already reached 100 Million (Duerden, 2019).

Brands play an important role in football as both benefit from each other. Sportswear manufacturers like Nike and Adidas compete to get licenses. Adidas produces the most famous balls. On the other hand, Nike contracts with more players. Nike's strategy involves nourishing young talent while Adidas strives to nourish the charisma of the ball. Meanwhile, different nations are also benefiting from the industry, such as Pakistan producing more than half of the world's football balls while employing around 60,000 people (Cooper \& Molloy, 2020). In the following sections, important stakeholders of the football industry are discussed.

\subsection{Clubs, and national teams}

Football clubs are the most important part of the football industry, and they have multiple ways to produce revenues for the clubs and their owners. First of all, the traditional method of selling tickets and jerseys and even some tours are available to the well-known clubs home stadiums such as Santiago Bernabeu, Nou Camp, and Wembley, the home of the English national football team.

Secondly, brands and sponsors are keen to cooperate with the clubs and teams since it's one way of advertisement and additional sale. Five times winner (the most) of the World Cup, Brazil national football team wears a Nike jersey for a reason, they made the biggest deal for a national team side in 1996, a $£_{100 m}$ contract between the Brazilian Football Confederation (CBF) and Nike (Reuters, 2015). 
Nowadays, many billionaires are interested in football clubs, that's why many top European clubs have foreign owners from different continents. For example, one of the giant clubs of Europe, Manchester City is owned by Sheikh Mansour, who is a member of the royal family from Abu Dhabi and the deputy prime minister of the United Arab Emirates. Another billionaire Zhang Kanyang was born in Nanjing and is the son of Zhang Jindong, the founder of Suning (Reuters, 2019b). 21\% of top European clubs are owned by Asians, as shown in Table 1.

While some clubs solve their economic problem by finding new owners or getting sponsorships from different brands, small clubs found their solution by developing young talents into superstars and selling them to the rich clubs. The most expensive player transfer in history was Neymar Jr from Barcelona to Paris Saint Germain (PSG) with a cost of \$263 Million for a transfer fee and a five-year contract with a $\$ 350$ million salary to the player (Hayward, 2017). It should be noted that the transfer fee is "the amount of money that a sports team pays to buy a new player from another team" (Cambridge Dictionary, 2021).

How much is a club worth if a single player can be worth hundreds of millions of US dollars? Some clubs are owned by citizens of the city or a country, where it's valued as their symbol. Table 2 shows the most valuable football clubs in the world. The best spot had been monopolized by two groups for the past 16 years, with the Real Madrid side taking it five times and England's Manchester United leading 11 times. Since the last time when Forbes announced the list in 2018, the top 20 club's value has increased by $30 \%$ on average (Ozanian, 2021).

Interestingly, football clubs (FCs) income changes due to their victories and actions. Even one player transfer can play a big role in the club's future. As mentioned before, Neymar Jr was the biggest transfer either in the transfer fee or role in the next few years. His ex-club FC Barcelona suffered in European competitions in the next few years without Neymar Jr. Table 3. That's why the Catalan pride (FC Barcelona) couldn't catch their rival Real Madrid CF's revenue for years, except 2021, concluding from Table 3. In contrast, Neymar helped his new club PSG get more TV rights and fans. In short, people wanted to see Neymar, so they bought PSG tickets and products. Even the French top division received more TV broadcasting offers than the previous year.

Table 1. Number of foreign owners of top division football clubs in Europe in 2018, by origin

\begin{tabular}{|c|c|}
\hline Region & Share of foreign owners (by \%) \\
\hline Europe & 46 \\
\hline North America & 25 \\
\hline Asia & 21 \\
\hline Other & 8 \\
\hline
\end{tabular}

Table 2. Most valuable football clubs in the world

\begin{tabular}{|c|c|c|c|c|c|}
\hline Logos & Rank & Name & Value & Revenue (2020) & Nation \\
\hline & 1 & Barcelona & $\$ 4.76 \mathrm{~B}$ & $\$ 792$ Million & Spain \\
\hline & 2 & Real Madrid & $\$ 4.75 B$ & $\$ 792$ Million & Spain \\
\hline & 3 & Bayern Munich & $\$ 4.22 \mathrm{~B}$ & $\$ 703$ Million & Germany \\
\hline & 4 & Manchester United & $\$ 4.2 \mathrm{~B}$ & \$643 Million & England \\
\hline (1) & 5 & Liverpool & $\$ 4.1 \mathrm{~B}$ & \$619 Million & England \\
\hline
\end{tabular}

Source: Forbes (2021c) 


\subsection{Leagues and tournaments}

The national teams and clubs have separate meanings in the case of organizing. Clubs pay the player's salary, making a contract of constant training with specific demands. On the other hand, national teams are allowed to gather in a specific duration between the league matches.

The most popular international football tournament is the World Cup organized by FIFA because people see the victory in this competition as a matter of the nation's glory. Famous players and referees choose FIFA World Cup rather than the Olympics football, making the Jules Rimet Trophy (World Cup Trophy) more important than the Olympics gold medal. Hence, many advanced economies always try to host the World cup. The last time France won the tournament was when the World Cup was hosted in Russia in 2018. USA, Mexico and Canada decided to host the 2026 world cup during the 68 $8^{\text {th }}$ FIFA conference held in Moscow in 2018. While Qatar, a rich Arab country, is about to host for the first time in 2022 (FIFA, 2018b). Only 3 examples of last and next world cup host nations can show the interest of the states. Those states are willing to host because the competition can bring millions of tourists, and sell hundreds of broadcasting rights. From Table 4, the international football development is visible, the first World Cup had 13 qualifying nations, while the 2022 World cup included 211 nations in its qualifying stage.

Table 3. FC Barcelona and Real Madrid CF's European success and operating income

\begin{tabular}{|c|c|c|c|c|}
\hline Season & $\begin{array}{l}\text { Barcelona Success in } \\
\text { UCL }\end{array}$ & $\begin{array}{l}\text { Barcelona's } \\
\text { Operating } \\
\text { Income }^{2}\end{array}$ & $\begin{array}{l}\text { Real Madrid Success in } \\
\text { UCL }\end{array}$ & $\begin{array}{l}\text { Real Madrid's } \\
\text { Operating } \\
\text { Income }^{2}\end{array}$ \\
\hline $2015^{1}$ & Winner & 174 & Semi-final & 170 \\
\hline $2016^{1}$ & Quarter-final & 108 & Winner & 162 \\
\hline $2017^{1}$ & Quarter-final & 102.1 & Winner & 181 \\
\hline 2018 & Quarter-final & 111 & Winner & 94 \\
\hline 2019 & Semi-final & -37 & Round of 16 & 112 \\
\hline 2020 & Quarter-final & - & Round of 16 & - \\
\hline 2021 & Round of 16 & 62 & Semi-final & 92 \\
\hline
\end{tabular}

Table 4. List of the World Cup hosts, winners and balls until 2022

\begin{tabular}{|l|c|c|c|c|}
\hline Year & Host nation & Winning nations & Balls & Qualifying nations \\
\hline 1930 & Uruguay & Uruguay & Tiento, T-model & 13 \\
\hline 1934 & Italy & Italy & Federale 102 & 32 \\
\hline 1938 & France & Italy & Allen & 37 \\
\hline 1950 & Brazil & Uruguay & Duplo T & 34 \\
\hline 1954 & Switzerland & West Germany & Swiss World Champion & 55 \\
\hline 1958 & Sweden & Brazil & Top Star & 56 \\
\hline 1962 & Chile & Brazil & Crack & 74 \\
\hline 1966 & England & England & Challenge 4-Star & 75 \\
\hline 1970 & Mexico & Brazil & Telstar & 99 \\
\hline 1974 & West Germany & West Germany & Telstar Durlast & 107 \\
\hline 1978 & Argentina & Argentina & Tango & 109 \\
\hline 1982 & Spain & Italy & Tango España & 121 \\
\hline 1986 & Mexico & Argentina & Azteca & 147 \\
\hline 1990 & Italy & West Germany & Etrusco Unico & 174 \\
\hline 1994 & The United States & Brazil & Questra & 199 \\
\hline 1998 & France & France & Tricolore & 198 \\
\hline 2002 & South Korea, Japan & Brazil & Fevernova & 206 \\
\hline 2006 & Germany & Italy & Teamgeist & 203 \\
\hline 2010 & South Africa & Spain & Jabulani & 210 \\
\hline 2014 & Brazil & Germany & Brazuca & 211 \\
\hline 2018 & Russia & France & Telstar 18 & (Pending) \\
\hline 2022 & Qatar & (Pending) & & Source: FIFA (2013a, 2021e, 2021g) \\
\hline & & & & \\
\hline
\end{tabular}


As aforesaid, just like the most valuable FCs are from Europe their associations and competitions are the most viewed and most famous at the club level. The Union of European Football Association's (UEFA) UEFA Champions League (UCL) is the most famous tournament that is held between the clubs, as 380 million people watched the UCL Final match in 2014 (Ashby, 2014). It was a match between two Spanish giants Real Madrid C.F against Club Atlético de Madrid held in Lisbon, Portugal.

Almost every country has its national leagues. Among them, the English Premier League (EPL) is known the most. The reason is their high-level football with a lot of competition, in other words, the league's teams level are close to each other, and that level average is top class. One of the main objectives of the EPL is to make the most competitive league with world-class players (Premier League, 2021a).

From Table 5, one can see that Manchester United are leading the list of revenue even though they finished 6th in the season of 2018/19. On the other hand, Manchester City won the EPL in the same season (Premier League, 2019a), positioning 2nd on the revenue table. This shows that Manchester United's income is from the sponsorships and their fans all around the world. They have 142 million social media followers (Goal, 2021). EPL clubs are creating around 100,000 jobs and supporting football development all over the world (Premier League, 2021b). EPL organization also supports its clubs' operations economically by paying them from the broadcasting and other revenues. Table 6 shows the 2018/19 season payments to the clubs from the league. Table 6 shows that league position can be related to the payment, Manchester City and Liverpool lead the table with 1st and 2nd position, respectively. Also, they're the most paid on this list. However, most of the teams are paid close enough, where the number of teams who got $£ 120$ million and above is 10 - half of the league's total clubs.

\subsection{Associations}

As previously mentioned, FIFA is the biggest association in football, having 211 member associations. Also, FIFA supports its members through numerous programs, even helping financially to the associations and countries. 6 international organizations are members of FIFA.

Table 5. Premier League clubs and their three attributes in the 2018/19 season.

\begin{tabular}{|c|c|c|c|}
\hline Club Name & $\begin{array}{c}\text { Revenue } \\
\text { (in million } £ \text { ) }\end{array}$ & League position & $\begin{array}{c}\text { Wage/Revenue ratio } \\
(\%)\end{array}$ \\
\hline Manchester United & 627 & 6 & 56 \\
\hline Manchester City & 538 & 1 & 59 \\
\hline Liverpool FC & 533 & 2 & 58 \\
\hline Tottenham Hotspur & 459 & 4 & 39 \\
\hline Chelsea & 452 & 3 & 70 \\
\hline Arsenal & 393 & 5 & 60 \\
\hline West Ham United & 193 & 10 & 70 \\
\hline Everton FC & 188 & 8 & 85 \\
\hline Leicester City & 179 & 9 & 83 \\
\hline Newcastle United & 176 & 13 & 55 \\
\hline Wolverhampton & 172 & 7 & 53 \\
\hline Crystal Palace & 154 & 12 & 78 \\
\hline Southampton & 150 & 16 & 77 \\
\hline Watford & 147 & 11 & 57 \\
\hline $\begin{array}{c}\text { Brighton \& Hove } \\
\text { Albion }\end{array}$ & 143 & 17 & 71 \\
\hline Burnley & 139 & 15 & 62 \\
\hline Fulham & 137 & 19 & 67 \\
\hline Bournemouth & 131 & 14 & 85 \\
\hline Cardiff City & 125 & 18 & 43 \\
\hline Huddersfield Town & 122 & 20 & 53 \\
\hline
\end{tabular}


Table 6. Premier League payments $(\AA)$ to clubs 2018/19 season

\begin{tabular}{|c|c|c|c|c|c|c|c|}
\hline Clubs & $\begin{array}{l}\text { UK } \\
\text { Live }\end{array}$ & $\begin{array}{l}\text { Equal } \\
\text { Share }\end{array}$ & $\begin{array}{c}\text { Facility } \\
\text { Fees }\end{array}$ & $\begin{array}{c}\text { Merit } \\
\text { Payment }\end{array}$ & $\begin{array}{c}\text { Internatio } \\
\text { nal } \\
\text { TV }\end{array}$ & $\begin{array}{c}\text { Central } \\
\text { Commerc } \\
\text { ial }\end{array}$ & $\begin{array}{c}\text { Total } \\
\text { Payment }\end{array}$ \\
\hline $\begin{array}{l}\text { Manchester } \\
\text { City }\end{array}$ & 26 & $34,361,519$ & $30,104,476$ & $38,370,360$ & $43,184,608$ & $4,965,392$ & $150,986,355$ \\
\hline Liverpool & 29 & $34,361,519$ & $33,461,785$ & $36,451,842$ & $43,184,608$ & $4,965,392$ & $152,425,146$ \\
\hline Chelsea & 25 & $34,361,519$ & $28,985,373$ & $34,533,324$ & $43,184,608$ & $4,965,392$ & $146,030,216$ \\
\hline $\begin{array}{c}\text { Tottenham } \\
\text { Hotspur }\end{array}$ & 26 & $34,361,519$ & $30,104,476$ & $32,614,806$ & $43,184,608$ & $4,965,392$ & $145,230,801$ \\
\hline Arsenal & 25 & $34,361,519$ & $28,985,373$ & $30,696,288$ & $43,184,608$ & $4,965,392$ & $142,193,180$ \\
\hline $\begin{array}{l}\text { Manchester } \\
\text { United }\end{array}$ & 27 & $34,361,519$ & $31,223,579$ & $28,777,770$ & $43,184,608$ & $4,965,392$ & $142,512,868$ \\
\hline $\begin{array}{l}\text { Wolverham } \\
\text { pton }\end{array}$ & 15 & $34,361,519$ & $17,794,343$ & $26,859,252$ & $43,184,608$ & $4,965,392$ & $127,165,114$ \\
\hline Everton & 18 & $34,361,519$ & $21,151,652$ & $24,940,734$ & $43,184,608$ & $4,965,392$ & $128,603,905$ \\
\hline $\begin{array}{l}\text { Leicester } \\
\text { City }\end{array}$ & 15 & $34,361,519$ & $17,794,343$ & $23,022,216$ & $43,184,608$ & $4,965,392$ & $123,328,078$ \\
\hline $\begin{array}{l}\text { West Ham } \\
\text { United }\end{array}$ & 16 & $34,361,519$ & $18,913,446$ & $21,103,698$ & $43,184,608$ & $4,965,392$ & $122,528,663$ \\
\hline Watford & 10 & $34,361,519$ & $12,198,828$ & $9,185,180$ & $43,184,608$ & $4,965,392$ & $113,895,527$ \\
\hline $\begin{array}{l}\text { Crystal } \\
\text { Palace }\end{array}$ & 12 & $34,361,519$ & $14,437,034$ & $17,266,662$ & $43,184,608$ & $4,965,392$ & $114,215,215$ \\
\hline $\begin{array}{c}\text { Newcastle } \\
\text { United }\end{array}$ & 19 & $34,361,519$ & $22,270,755$ & $15,348,144$ & $43,184,608$ & $4,965,392$ & $120,130,418$ \\
\hline $\begin{array}{c}\text { AFC } \\
\text { Bournemo } \\
\text { uth }\end{array}$ & 10 & $34,361,519$ & $12,198,828$ & $13,429,626$ & $43,184,608$ & $4,965,392$ & $108,139,973$ \\
\hline Burnley & 11 & & $3,317,931$ & & $43,184,608$ & $4,965,392$ & $107,340,558$ \\
\hline $\begin{array}{c}\text { Southampt } \\
\text { on }\end{array}$ & 10 & $34,361,519$ & $12,198,828$ & $9,592,590$ & $43,184,608$ & $4,965,392$ & $104,302,937$ \\
\hline $\begin{array}{c}\text { Brighton \& } \\
\text { Hove } \\
\text { Albion }\end{array}$ & 13 & $34,361,519$ & $15,556,137$ & $7,674,072$ & $43,184,608$ & $4,965,392$ & $105,741,728$ \\
\hline Cardiff City & 12 & & & & $43,184,608$ & $4,965,392$ & $102,704,107$ \\
\hline Fulham & 13 & & $15,556,137$ & $3,837,036$ & $43,184,608$ & $4,965,392$ & $101,904,692$ \\
\hline $\begin{array}{c}\text { Huddersfiel } \\
\text { d Town }\end{array}$ & 10 & $34,361,519$ & $12,198,828$ & $1,918,518$ & $43,184,608$ & $4,965,392$ & $96,628,865$ \\
\hline \multicolumn{2}{|l|}{ Total } & $\begin{array}{c}\text { f687,230, } \\
380\end{array}$ & $\begin{array}{c}f^{402,889}, \\
186\end{array}$ & $\begin{array}{c}f_{402,888} \\
780\end{array}$ & $\begin{array}{c}\AA^{863,692,1} \\
60\end{array}$ & $\begin{array}{c}£ 99,307,8 \\
40\end{array}$ & $\begin{array}{c}£ 2,456,008, \\
346\end{array}$ \\
\hline
\end{tabular}

The AFC in Asia, CAF in Africa, the Football Confederation (CONCACAF) in North and Central America and the Caribbean, CONMEBOL in South America, Union of European Football Associations (UEFA) in Europe and the OFC in Oceania are regional officials that focus on the development of football, football tournaments alongside FIFA (FIFA, 2021f). Football associations make the regulations and officials of the matches such as refereeing, appointing.

Table 7 shows us that FIFA's strategy in the budget has changed after the 2014 World Cup. From the South Africa World Cup 2010, they had positive results every year until 2014, and then they were putting more expenses than the revenue to get a higher profit from the 2018 World Cup. Moreover, the difference between a year without World cup and a year with World cup is smaller before 2015, such as the \$69Million profit difference between FIFA's 2014 and 2013 net financial result. While the year 2018's profit, when the World Cup in Russia was held, has a \$2004Million profit difference from the year 2017's net financial result (see Table 7).

The 2018 World cup brought the highest revenue to FIFA in World Cup history. Ticket sales, broadcasting rights, hospitality rights, and marketing rights all exceeded their budget targets and contributed to the highest revenue. As the FIFA statement claims, the revenue is $\$ 5,357$ million covers the full 2015-2018 financial cycle from the World Cup 2018. The average attendance of 
Table 7. FIFA's revenue, reserves and expenses by year (in Million USD)

\begin{tabular}{|c|c|c|c|c|c|}
\hline Year & Revenue & Expenses & Reserves & $\begin{array}{c}\text { Financial } \\
\text { result before } \\
\text { taxes }\end{array}$ & $\begin{array}{c}\text { Net financial } \\
\text { result for the } \\
\text { year }\end{array}$ \\
\hline $2010^{*}$ & 1,164 & $-1,039$ & 1,280 & 125 & 202 \\
\hline 2011 & 1,040 & $-1,012$ & 1,293 & 28 & 36 \\
\hline 2012 & 1,077 & $-1,000$ & 1,378 & 77 & 89 \\
\hline 2013 & 1,383 & $-1,236$ & 1,432 & 147 & 72 \\
\hline $2014^{*}$ & 1988 & $-1,798$ & 1,523 & 190 & 141 \\
\hline 2015 & 544 & -661 & 1,410 & -117 & -52 \\
\hline 2016 & 502 & -893 & 1,048 & -391 & -368 \\
\hline 2017 & 734 & -923 & 930 & -189 & -191 \\
\hline $2018^{*}$ & 4,641 & $-2,891$ & 2,745 & 1,750 & 1,813 \\
\hline 2019 & 765 & $-1,046$ & 2,585 & -280 & -185 \\
\hline 2020 & 266 & $-1,044$ & 1,880 & -778 & -683 \\
\hline
\end{tabular}

$98.2 \%$ stadium capacity was remarkable. The total number of people who attended matches was 3,031,768. In addition, World Champion France received $\$ 38$ Million as a prize for winning the World Cup (FIFA, 2019, p. 34-41).

Throughout the history of football, European football leagues and tournaments have been more famous than the other continents. Why is it in Europe? Because, modern football method was firstly invented in England moreover, 7 European national teams are in the top 10 of FIFA's ranking (FIFA, 2021c). The mentionable continent is, of course, South America having the countries that have 9 world cup trophies between, also street football is found everywhere in some countries. One example is the five-times World Cup winner (the most) Brazil. It is called a country of football for a reason. The largest attendance at a single football match was 173,850 for the match between Uruguay versus Brazil to decide the World Cup winner. That historical match was at Maracanã Stadium in Rio de Janeiro, Brazil, on 16 July 1950 (Guinness World Records, 2021).

However, Germany and Italy each have 4 world cup titles, France two, England and Spain having one each makes a total of 12 times the world cup winners from Europe, which is the most successful continent. UEFA and its plans are role models for other countries since the most famous club football competitions are in Europe too (UEFA, 2021a; 2021b).

Table 8 shows that UEFA's revenue is even greater than FIFA's even though FIFA is the biggest governing body of football. For instance, the revenue of UEFA between 2015 to 2018 was

$$
(€ 2099.4+€ 4579.8+€ 2835.9+€ 2789.8) \text { Million }=€ 12304.9 \text { Million (Table 8), }
$$

and the revenue of FIFA in the same period was

$$
(\$ 544+\$ 502+\$ 734+\$ 4641) \text { Million }=\$ 6421 \text { Million (Table 7), }
$$

which is approximately $€ 5234$ Million (calculated by May 31, 2021's USD/EUR exchange rate).

Following its high revenue, UEFA also spends a lot on the development of football, because their main objective is to invest as much as possible in European football. Unfortunately, the Euro 2020 competition for European champion of national teams is postponed to 2021's summer due to the covid-19 pandemic. Despite the threat from coronavirus, UEFA managed to run the football domestic leagues and UCL during this hard time. UEFA created a Return To Play Protocol that built up operational and restorative rules for organizing around 1,500 matches and executing more than 125,000 COVID-19 tests since August 2020 (UEFA, 2021c).

Corruption is another issue affecting the revenue of associations. In February 2016, former general secretary of UEFA, Gianni Infantino was elected as FIFA's president to restore FIFA's image after the 2015 FIFA corruption scandal (BBC, 2016). If we look back at the key events of punishing the guilty executives of FIFA, we may start with the 27th of May 2015, when seven officials of FIFA, were arrested in Zurich by Swiss police. Under the Federal Bureau of Investigation's scrutiny, several FIFA officials and two continental authorities, which are from CONCACAF and CONMEBOL, were all charged with things like "racketeering, wire fraud, and 
money laundering conspiracies." On December 21, the FIFA Ethics Committee banned both Sepp Blatter (ex-president of FIFA) and Michel Platini (ex-president of UEFA) for eight years from all football-related activities organized by FIFA (Onwumechili \& Bedeau, 2016).

\subsection{Brands}

If clubs and associations are responsible for managing the football matches and tournaments, how do they gain other than ticket sales and merchandising? The answer is sponsors and brands that are from other departments. The most famous among them are Coca-Cola and Pepsi, while Coca-Cola cooperates with FIFA World Cup while their competitor Pepsi is sponsoring UEFA Champions League for many years. When it comes to Football kits and gears manufacturing, Adidas and Nike are dominant producers and sponsors in the football world. Firstly, some examples of sponsorships will be mentioned with some data, and then the aftermath will be included. In 2020, the world economy was hurt by the pandemic, and the countries had no choice but to lock down their people to minimize the spread of the virus, resulting in the curb of outdoor activities, including Football events. Thus, along with the tourism and traveling industry, the Football Industry was another victim of this pandemic period (Gopinath, 2020). Following the COVID-19 induced economic disruptions, most of the companies faced a drop in their sales. Even the largest sportswear manufacturers, Nike and Adidas. Both brands had revenue of $\$ 66$ billion combined Nike's sales dropped by around $4.3 \%$ in 2020, while that of Adidas slumped $16 \%$. Table 9 shows the revenue of Nike, Adidas and Puma in recent years.

Puma is the closest competitor to Nike and Adidas, but concluding from the difference of the revenue of Puma and the 2 giants, one can see that Nike and Adidas are dominant in the sportswear industry. Since 1970, Adidas has owned the license of the World Cup official balls. Furthermore, Nike-sponsored players were successful in the 2018 World Cup, such as both finalists, the national teams of France and Croatia, were sponsored by Nike. Also, the golden boot winner (highest goal scorer) Harry Kane, the best young player Kylian Mbappe and the golden ball winner Luka Modric were all sponsored by Nike. Interestingly, some of those world cup awards are named after Adidas because of its partnership with FIFA World Cu example, Adidas Golden Ball is for the best player of the tournament, Adidas Golden Boot is for the top scorer, and Adidas Golden Glove is for the best goalkeeper in the tournament (FIFA, 2021a).

In 2013, Adidas renewed its contract with FIFA until 2030 to be the supplier and licensee rights for the FIFA World Cup. As FIFA claimed, FIFA referees, officials, and the entire youth program wear Adidas products from head to toe whilst they also use the Adidas balls, gears, and workout accessories (FIFA, 2021b)."Over the last 40 years, Adidas and FIFA have worked closely together to develop football worldwide. Therefore, it was a natural step for us to extend one of the most successful partnerships in the history of sports marketing", CEO of the Adidas Group Herbert Hainer said in 2013 when he was attending the ceremony with FIFA Marketing Director Thierry Weil in Moscow (FIFA, 2013b). The previous statement clarifies the importance of cooperation between the football associations and brands. It's not possible to calculate the exact amount of the expenses on football from the brands because most companies don't announce every contract with clubs and associations. While only some are revealed to the public, such as deals between the famous clubs and brands are known. Let's see the most valuable kit deals in the world according to the reliable news publishers of Europe such as Reuters, since the real contract details are announced publicly by neither the club nor brand. Table 10 shows the most expensive kit license deals in football's history.

In short, sportswear manufacturers pay for the license rights for using the football club. The reason is that the products belong to the manufacturer. Depending on the contract between the parties, clubs can gain from each sale; for instance, Liverpool's deal with Nike mentions that $20 \%$ of the sales commission goes to Merseyside (Liverpool) (Metro, 2020). That makes real sense, both clubs and brands can benefit from the shirt sales. On the other side, fans will receive the finest products from their favorite club. This logic is identical with national teams, where the associations 
Table 8. UEFA's revenue, expenses, matches played \& UCL prize and winners (in Million EUR)

\begin{tabular}{|c|c|c|c|c|c|c|}
\hline Season & Revenue & Expenses & $\begin{array}{c}\text { Net Result } \\
\text { (after } \\
\text { solidarity } \\
\text { payments) }\end{array}$ & $\begin{array}{c}\text { Matches } \\
\text { Played }\end{array}$ & $\begin{array}{c}\text { UCL } \\
\text { Winner } \\
\text { Prize }\end{array}$ & $\begin{array}{c}\text { UCL Winner } \\
\text { Club }\end{array}$ \\
\hline $2018 / 19$ & 3857.2 & -3638.6 & -46.4 & 2354 & 111.1 & Liverpool (ENG) \\
\hline $2017 / 18$ & 2789.8 & -2515.2 & -5.0 & 2090 & 88.7 & $\begin{array}{c}\text { Real Madrid } \\
\text { (ESP) }\end{array}$ \\
\hline $2016 / 17$ & 2835.9 & -2558.4 & -6.7 & 2073 & 81.1 & $\begin{array}{c}\text { Real Madrid } \\
\text { (ESP) }\end{array}$ \\
\hline $2015 / 16$ & 4579.8 & -3310.2 & 3.8 & 2089 & 80.1 & $\begin{array}{c}\text { Real Madrid } \\
\text { (ESP) }\end{array}$ \\
\hline $2014 / 15$ & 2099.4 & -1976.6 & 102.1 & 1992 & 61 & Barcelona (ESP) \\
\hline $2013 / 14$ & 1730.4 & -1614.6 & -27.9 & 1891 & 60.4 & $\begin{array}{c}\text { Real Madrid } \\
\text { (ESP) }\end{array}$ \\
\hline $2012 / 13$ & 1698.9 & -1575.7 & -42.4 & 1662 & 56.6 & $\begin{array}{c}\text { Bayern Munich } \\
\text { (GER) }\end{array}$ \\
\hline $2011 / 12$ & 2795.7 & -2059.2 & 128.8 & 1868 & 62.9 & Chelsea (ENG) \\
\hline $2010 / 11$ & 1384.1 & -1308.7 & -85.9 & 1890 & 53.2 & Barcelona (ESP) \\
\hline
\end{tabular}

Table 9. The Revenue of Nike, Adidas and Puma in recent years

\begin{tabular}{|c|c|c|c|c|c|c|c|c|c|c|}
\hline & $2020^{*}$ & 2019 & 2018 & 2017 & 2016 & 2015 & 2014 & 2013 & 2012 & 2011 \\
\hline Nike & 33.6 & 35.13 & 31.35 & 30.57 & 29.1 & 27.51 & 24.99 & 22.75 & 20.97 & 18.08 \\
\hline Adidas & 19.8 & 23.64 & 21.92 & 21.22 & 18.48 & 16.92 & 14.53 & 14.2 & 14.88 & 13.32 \\
\hline Puma & 5.2 & 5.5 & 4.65 & 4.14 & 3.63 & 3.39 & 2.97 & 2.99 & 3.27 & 3.17 \\
\hline
\end{tabular}

Note: All revenues are in Billion Euros.

Table 10. Most expensive kit license deals in football

\begin{tabular}{|c|c|c|c|c|c|}
\hline Clubs & $\begin{array}{c}\text { Club's } \\
\text { origin }\end{array}$ & Brands & $\begin{array}{c}\text { Deal worth per } \\
\text { year }\end{array}$ & $\begin{array}{c}\text { Contract } \\
\text { (Million } \\
\text { starting } \\
\text { year }\end{array}$ & Source \\
\hline Barcelona & Spain & Nike & 140 & 2018 & $\begin{array}{c}\text { Skysports } \\
(2016)\end{array}$ \\
\hline Real Madrid & Spain & Adidas & 120 & 2020 & Reuters (2019a) \\
\hline Manchester United & England & Adidas & 75 & 2015 & Wilson (2014) \\
\hline Paris Saint-Germain & France & Nike & 75 & 2019 & Johnson (2019) \\
\hline Manchester City & England & Puma & 65 & 2020 & BBC (2019) \\
\hline Arsenal & England & Adidas & 60 & 2019 & Reuters (2018) \\
\hline Chelsea & England & Nike & 60 & 2017 & Wilson (2016) \\
\hline Juventus & Italy & Adidas & 46 & 2018 & Shergold (2018) \\
\hline Bayern Munich & Germany & Adidas & 43 & 2016 & Akerman (2015) \\
\hline Liverpool & England & Nike & 30 & 2020 & Metro (2020) \\
\hline
\end{tabular}

cooperate with manufacturers. Table 11 shows ten best-selling football jerseys by a club in the 2018/19 season.

There are sponsors who don't work in the football industry, including the Fly Emirates, Samsung etc. Companies do marketing by putting their names or logos on the jersey of the football clubs. They are usually companies of oligopoly markets, where it demands advertising a lot. Because football is the most-watched sport, as mentioned earlier, 3.5 Billion people watched at least 1 minute of the FIFA World Cup (FIFA, 2018c), so it is a great advertising opportunity. Some are equivalent to advertisements in the movies. Batman drives Mercedes Benz, while Real Madrid players drive an Audi car. Table 12 shows most expensive sponsorships on the shirt of football clubs.

The origin countries of the sponsors and clubs intimate how intercontinental the sponsorship business can be. $100 \%$ of the clubs are from Europe, however, only 4 out of 10 sponsors are from Europe. 
Table 11. Ten Best-selling football jerseys by a club in the 2018/19 season

\begin{tabular}{|c|c|c|c|c|c|c|c|c|c|c|}
\hline$\frac{\mathscr{n}}{\Xi}$ & 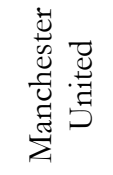 & 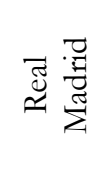 & 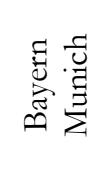 & 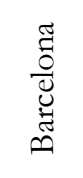 & 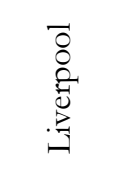 & 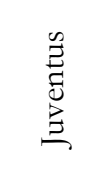 & 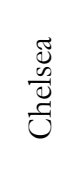 & 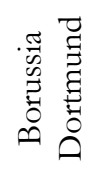 & 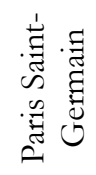 & 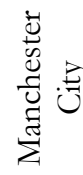 \\
\hline In 1000 Units & 3250 & 3120 & 2575 & 1925 & 1670 & 1615 & 1525 & 1205 & 1146 & 1085 \\
\hline Manufacturer & Adidas & Adidas & Adidas & Nike & $\begin{array}{c}\text { New } \\
\text { Balance }\end{array}$ & Adidas & Nike & Puma & Nike & Nike \\
\hline
\end{tabular}

Table 12. Most expensive sponsorships on the shirt of football clubs

\begin{tabular}{|c|c|c|c|c|}
\hline Clubs & Club's origin & Sponsors & $\begin{array}{c}\text { Sponsor's } \\
\text { origin }\end{array}$ & $\begin{array}{c}\text { Annual Worth } \\
\text { (in Million £) }\end{array}$ \\
\hline Real Madrid & Spain & Emirates & UAE & 60 \\
\hline Manchester United & England & Teamviewer & Germany & 47 \\
\hline Barcelona & Spain & Rakuten & Japan & 47 \\
\hline Paris Saint-Germain & France & Accor & France & 43 \\
\hline Chelsea & England & Three & Hong-Kong & 40 \\
\hline Manchester City & England & Etihad Airways & UAE & 39 \\
\hline Bayern Munich & Germany & T-Mobile & Germany & 36 \\
\hline Liverpool & England & Standard Chartered & England & 27 \\
\hline Arsenal & England & Emirates & UAE & 26 \\
\hline Tottenham & England & AIA & China & 25 \\
\hline \multicolumn{2}{|r}{}
\end{tabular}

\subsection{Broadcasting and other contents}

Football competitions were established before television became popular. For instance, the first World Cup was organized in 1930 (see Table 4), while the first-ever regularly scheduled TV service of BBC started in 1936 (BBC, 2021). In modern times, broadcasting is one of the main parts of the football industry. Because this is the tool to reach the people. 3.5 Billion people couldn't watch the World Cup without broadcasting due to the limited capacity of stadiums.

GermanBundesliga's average attendance rate was 42,738 in the 2018/19 season that brought $12.9 \%$ of the revenue. And $66.1 \%$ of the revenue in the same season came from broadcasting rights and other media-related revenues to the DFL, the association that organizes the Bundesliga of Germany (Horky, 2020).

Broadcasting rights will include some sponsorship content too, for instance, Lays and Heineken advertisements usually run with the UCL matches. Moreover, broadcasting rights price will depend on the size and region of the broadcaster. That's fair since bigger TV channels gain more, while smaller ones will broadcast the tournaments for improvement. The tournament or league organisers will give the media the right licenses. 4 types of media licenses (TV, Radio, Mobile and Internet) were given to broadcasters for the 2018 World Cup.

Broadcasting was the biggest source of revenue (55\%) for FIFA in the 2015-2018 cycle. 2018 World Cup was broadcasted to 220 territories and contributed 95\% of the full cycle's (2015-2018) media revenue of \$3,127 Million. Table 13 shows the FIFA revenue split between 2015 and 2018. Another fact was that Asian and North African territory exceeded Europe by their revenue brought to FIFA for the first time in history. That was $\$ 974$ Million in revenue from TV broadcasting rights (FIFA, 2019) was remarkable because it shows the development of the continent and the development of football broadcasting around the world. Table 13 shows FIFA revenue from 2015 to 2018.

There are other contents except for the match, such as pre-game shows, cinematic content made by the TV channels, but they follow the standard of media that the tournament organizers have set. Having the same format is very important when it comes to creating content worldwide. Following the e-business rise, even clubs and player have their digital content channels on the internet recently. For instance, the FC Barcelona YouTube channel had 3.7 Million subscribers (the 
Table 13. FIFA revenue split 2015-2018 (in Million USD)

\begin{tabular}{|l|l|l|l|l|l|}
\hline Source types/Years & $\mathbf{2 0 1 5}$ & $\mathbf{2 0 1 6}$ & $\mathbf{2 0 1 7}$ & $\mathbf{2 0 1 8}$ & Total \\
\hline Television broadcasting rights & 258 & 96 & 229 & 2,544 & 3,127 \\
\hline Marketing rights & 157 & 115 & 245 & 1,143 & 1,660 \\
\hline Licensing rights & 51 & 204 & 160 & 185 & 600 \\
\hline Hospitality/accommodation rights and ticket sales & 0 & 0 & 23 & 689 & 712 \\
\hline Other revenue & 78 & 87 & 77 & 80 & 322 \\
\hline Total & 544 & 502 & 734 & 4,641 & 6,421 \\
\hline
\end{tabular}

most) as of February 2018, but they have 11.5 Million subscribers (the most) as of June 2021 on the same platform. As seen in Table 2, FC Barcelona is the most valuable football club, and its online channel and contents are one of the leading examples of online media advertisement. Their sponsor Rakuten (a Japanese company) is visible on their YouTube channel's featured channel part. Moreover, contents also include advertisements, which are watched by millions of people (YouTube, 2021).

\section{Football and International Economy}

\subsection{Football and the socio-economic development of nations}

This section will highlight how nations benefit from the football industry and how some couldn't use the opportunities they had. As said before, in the leagues and tournaments section, the top tier tournaments have become clear by their quality and popularity. First of all, the FIFA World Cup, UEFA Champions League, and UEFA European Championship are the main events that bring the highest benefit to the countries. The World Cup is a powerful way to attract tourists, tourists that will expend a pretty good amount of money during the visit time. For instance, there are costs for travelling, food and drink, hotel or hostel, and the foreigners might do shopping during the time. Not every tourist that comes during the sports events is going to buy a ticket for the event. However, the amount of people purchasing a ticket is convincing.

According to FIFA (2018a), 11 cities of Russia hosted the 2018 World Cup and welcomed 7.7 million domestic and global visitors during the events. The capital city Moscow achieved the best attendance with 1,887,200 visitors. For the 2014 FIFA World Cup ${ }^{\text {TM }}$ in Brazil, the top venue Rio de Janeiro had 937,330 visitors in total and 5.2 million visitors overall in the country. Frankly speaking, Brazil hosted 2 mega-sport events in a row that are 2014 FIFA World Cup and the 2016 Summer Olympics to increase tourism and boost the economy. Brazil's receipt from foreigners has increased by 548 Million USD during the 2014 World Cup while rising again in 2016 during the Olympic games with an amount of 472 Million USD (Meurer \& Lins, 2017). This case is evidence that the football World Cup had higher support than the Olympics in Brazil.

Before the Brazil World Cup, South Africa FIFA World Cup was crucial not only to South Africa but also to the Africa continent. More than 15,000 media arrivals were recorded in that 2010 World Cup. Also the Waka Waka (The Official 2010 FIFA World Cup ${ }^{\text {TM }}$ Song) is the most popular football song with 2.8 Billion views on YouTube by now. The 2010 World Cup showed Africa's culture very well and became iconic with its differentiation. From Table 14, most of the respondents were from Europe and America. And Africans were just 17.6\%, which shows the tourism from other continents were quite higher in South Africa World Cup.

However, some mega-sport events were not successful as planned. The 2004 Athens Olympics in Greece was supposed to increase tourism in the long term and bring a boost to the economy. But it had little to no effect on the economy and tourism industry (Vierhaus, 2018, pp. 3-4).

The Prize pool is another way of gaining through participating in football events. The 2018 World Cup prize winners are shown in Table 15. The most recent World Champion, France's national football team received 38 Million USD total. This prize has been divided between the players and the association itself, respectively. In short words, it just goes to the people of France. 
That's equal to $80 \%$ of the Tuvalu GDP in 2019, which is 47.27 Million USD according to the World Bank (2021). Table 15 shows prize money for the 2018 FIFA World Cup.

For some countries, manufacturing a specific product or service for the football industry is a source of financial gains and economic development. For instance, Pakistan produces almost $70 \%$ of the football, football manufacturing also helps fight unemployment by creating 60,000 jobs in Pakistan (Cooper \& Molloy, 2020). Football manufacturing in Pakistan started in the early 1900s under the British colonialists. Since then, the region has produced hand-stitched footballs. Despite the technological development, Pakistan kept producing footballs by hand (and sometimes using child labour), and as a result, China recently took some portion from the football manufacturing space because of its advanced technology. In 2009, China had 50.5\% of the market share ahead of the South Africa World Cup; meanwhile, Pakistan only had 13.2\% of the market (Tanveer et al., 2012, p. 35). However, Pakistan was the main supplier for the World Cup 2018 and exported around 37 Million footballs that worth approximately \$153Million, which was the highest among the football manufacturing countries in 2018 (Khan, 2020). Those countries are preferred by the sports product giants Adidas, Nike, and others because of the cheaper labor. As a result of the international business, both sides are benefitting in their way.

Football stitching has always been a significant income source in the Sialkot area of Pakistan since the 1900s. Both factory-based, home-based, and centre-based football manufacturing are available in Sialkot and nearby villages. As seen in Table 16, a male worker from home earns monthly a 41.75 Euro, relatively low to the factory-based worker as a factory stitcher who collects 139.17 Euro at the same amount of time (Naz \& Bögenhold, 2020).

Table 14. Origin regions of respondents during the 2010 World Cup (in \%, n=4814)

\begin{tabular}{|c|c|c|c|c|c|c|c|}
\hline Region & Africa & Asia & $\begin{array}{c}\text { Australia/New } \\
\text { Zealand }\end{array}$ & Europe & $\begin{array}{c}\text { Middle } \\
\text { East }\end{array}$ & $\begin{array}{c}\text { North } \\
\text { America }\end{array}$ & $\begin{array}{c}\text { South } \\
\text { America }\end{array}$ \\
\hline Percentage & 17.6 & 8.3 & 7 & 37.8 & 1.2 & 11 & 17 \\
\hline
\end{tabular}

Table 15. Prize money for the 2018 FIFA World Cup (in Million USD)

\begin{tabular}{|c|c|c|}
\hline Position & Winning Teams & $\begin{array}{c}\text { Prize } \\
\text { Money }\end{array}$ \\
\hline Champions & France & 38 \\
\hline Runners-Up & Croatia & 28 \\
\hline Third Place & Belgium & 24 \\
\hline Fourth Place & England & 22 \\
\hline $5^{\text {th }} 8^{\text {th }}$ Place & Brazil, Russia, Sweden, Uruguay (each) & 16 \\
\hline $9^{\text {th }}-16^{\text {th }}$ Place & Argentina, Colombia, Denmark, Japan, Mexico, Portugal, Spain, \\
Switzerland (each) & 12 \\
\hline $17^{\text {th-32nd Place }}$ & $\begin{array}{c}\text { Australia, Costa Rica, Egypt, Germany, Iceland, Iran, Republic of Korea, } \\
\text { Morocco, Nigeria, Panama, Peru, Poland, Saudi Arabia, Senegal, Serbia, } \\
\text { Tunisia (each) }\end{array}$ & 8 \\
\hline Total & 32 teams & 400 \\
\hline \multicolumn{2}{|c|}{ Source: FIFA (2019, p. 37) }
\end{tabular}

Table 16. Earnings in football stitching in Pakistan, 2015

\begin{tabular}{|c|c|c|c|c|c|}
\hline Type of Stitchers & Gender & $\begin{array}{c}\text { Daily } \\
\text { Output }\end{array}$ & $\begin{array}{c}\text { Piece Rate } \\
\text { (PKR) }\end{array}$ & $\begin{array}{c}\text { Monthly } \\
\text { earnings } \\
\text { (PKR) }\end{array}$ & $\begin{array}{c}\text { Monthly } \\
\text { earnings } \\
\text { (EUR) }\end{array}$ \\
\hline Factory-based stitcher & Male & 6 & 100 & 15600 & 138.17 \\
\hline Centre-based stitcher & Male & 7 & $85-110$ & 15470 & 138.01 \\
\hline Centre-based stitcher & Male & 7 & $75-85$ & 13650 & 121.77 \\
\hline Family centre (4 members) & Female \& Male & 12 & $90-95$ & 28080 & 250.51 \\
\hline Female stitching centre & Female & 3 & 50 & 3900 & 34.79 \\
\hline Homeworker & Male & 3 & $60-65$ & 4680 & 41.75 \\
\hline Homeworker & Female & 3 & $32-55$ & 3900 & 34.79 \\
\hline
\end{tabular}




\subsection{Football development and FIFA}

Because FIFA is a governing body of football, the association also needs to invest in the development of football all around the world. As shown in Table 7, FIFA had 6,421 USD revenue from the events they organized, licensing rights, and other sources in the 2015-2018 cycle. Also, $81 \%$ of that revenue was invested in the football community differently. One of their main programs is FIFA Forward Programme, which is a support to FIFA's 211 member associations and the regional associations. After promising World Cup in 2018, FIFA decided to increase the investment to their member associations through the Forward 2.0 Programme in the 2019-2022 cycle (FIFA, 2019, p. 40-57). Figure 1 displays the FIFA Football Development Programmes sizes since 2011 and the planned budget until 2022.

\section{Discussion}

Based on the preceding discussions and literature reviewed, the current study proposes a comprehensive structure of the football industry (see Figure 2). Figure 2 shows that the payments and cooperation flow between the important parts that are compounding the football industry. For instance, Football players are paid by the Clubs and Sponsors. For Associations, this includes all the FIFA member associations and Figure 2 is not intending to show the structure of associations. Instead Figure 2 is more focused on the business compounding parts of the football industry. In Figure 2, arrows are the direction of the action they're doing. For instance, football clubs participate in the leagues and tournaments and get paid by the organizer associations. The reason to say that associations and clubs are cooperating is that most of the stadiums are owned by the clubs. So those clubs help with their stadiums to hold the matches, but they get paid in return. In rare cases, national teams have their independent stadiums. However, most of the stadiums are owned by the clubs.

Moreover, Fans or Customers are paying for the service or product they are getting, such as watching a live football match on TV, buying sportswear from the sponsor's shops. To note, both sports brands and non-football industry sponsors are included in the Sponsor Brands section. So Adidas and Rakuten are both counted in the same section, for example. Also, any type of sponsoring is included in the Sponsors section, such as TV broadcasters can have a deal with players or clubs to make content and sell. So in Figure 3, the TVs and broadcasters box includes only the cooperation between the leagues and tournament contents with broadcasters. Broadcasting brings the most of the revenue from football content. While other types of football

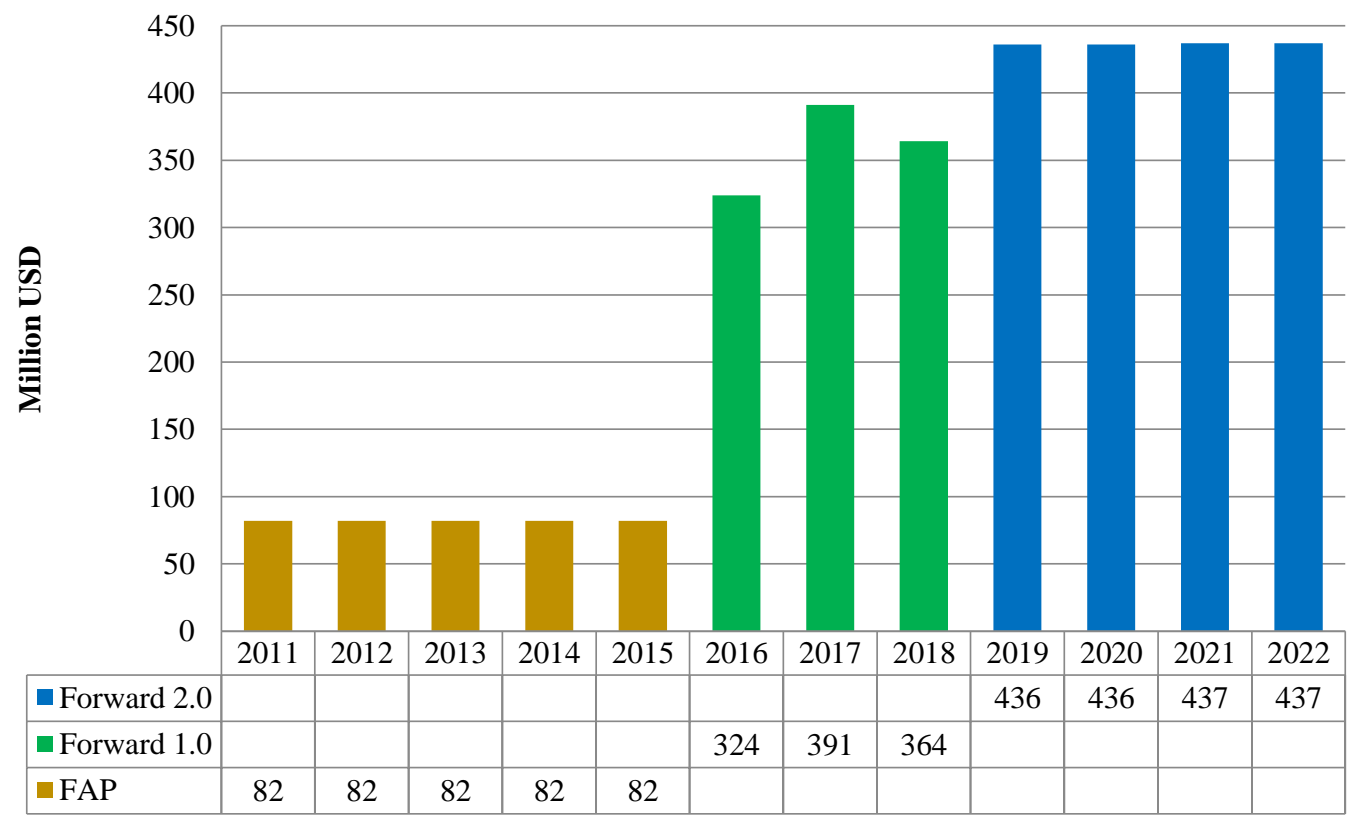

Figure 1. FIFA Football Development Programmes size 2011-2022 (Million USD) (Data: FIFA, 2019, p. 45) 


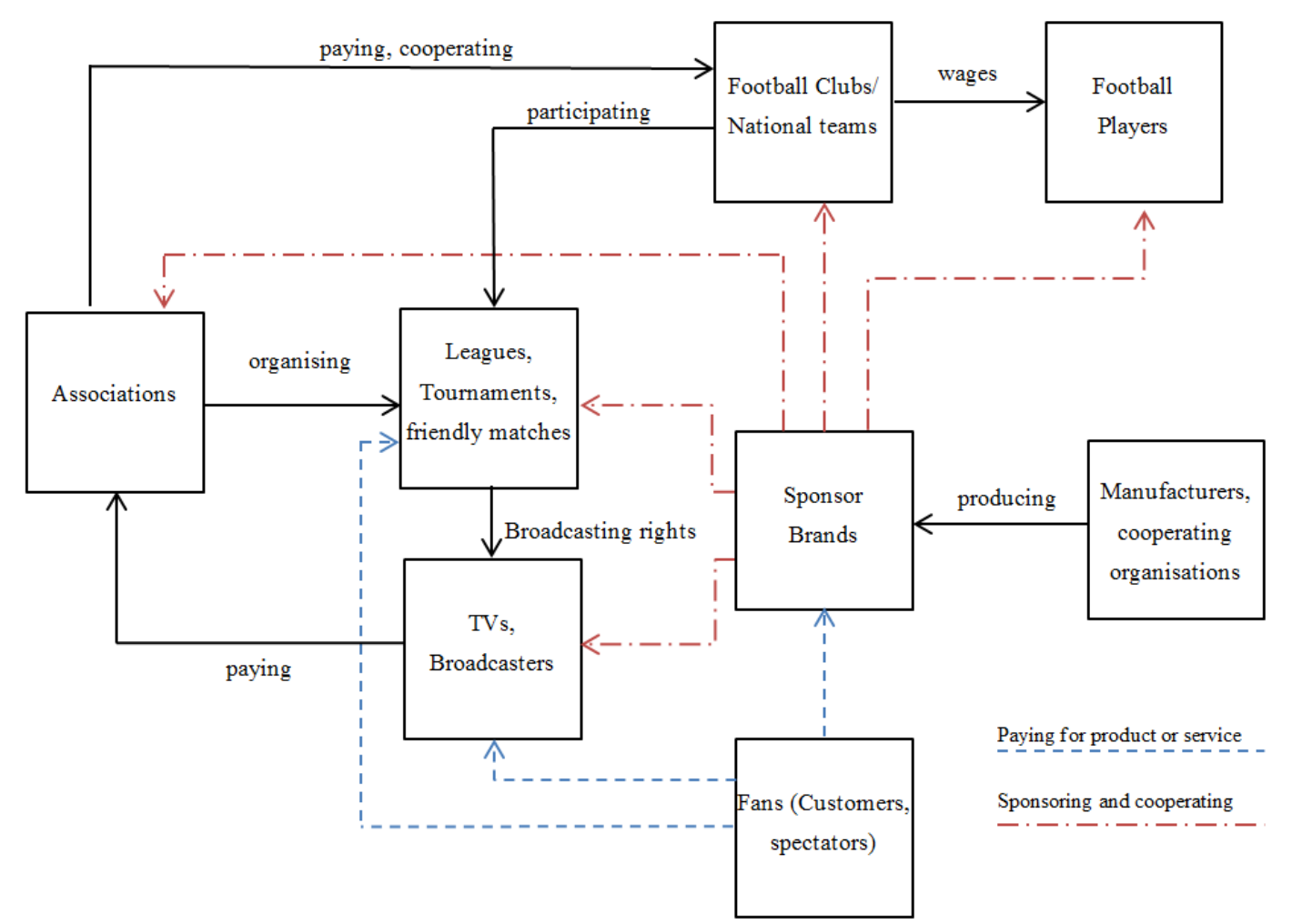

Figure 2. The structure of the global football industry

content that are related to individual players and clubs are included in the Sponsor Brands. Films such as Ronaldo [2015] and Toni Kroos [2019] are works of independent film producers and organizations outside of football broadcasting.

Guided by the literature reviewed in the current study, an overview of the so-called "toppers" in different categories of the football industry is presented in Table 17 for quick reference for the readers. Noticing from the research data, the names of the top associations and clubs don't frequently change through history because they are top-tier clubs and the main subjects of football for years. Some clubs are trying to become a brand like them with many financial sources from outside the industry, such as Manchester City in the list, whose owner is an Arab Sheikh, as mentioned before. On the other hand, top sponsors are always changing because of the change in the global market. In addition, 5 out of 8 sponsors are from Asia in this list, showing the recent economic rise of Asian countries.

\section{Conclusion}

Balancing economic growth with the needs of society and the environment is at the heart of sustainable economic development (Javed et al., 2021). Through investment in sports, countries not only provide their citizens with opportunities to stay healthy but sports in turn also becomes a source of revenue for the countries connected with it. One can argue that sports success is related to its nation's development. But financially independent people tend to spend more time on their hobbies, such as football. Another thing is that good governance brings top-level projects to sports development. Football serves a social function, comprises a series of public assets, and has several effects, which are generally good for a nation's socio-economic development. A country's economic performance positively influences its performance in football (Mendoza, 2017).

The current study made a pioneering attempt to report a comprehensive study of the football industry and its role in international trade and the economy. The study observed that football megaevents like World Cup can increase tourism significantly. The impact in international trade occurs at every level of the football industry because football itself is always creating international matches organized and sponsored by international cooperations, organizations, and firms worldwide. 
Table 17. An overview of the football industry

\begin{tabular}{|l|l|}
\hline Top associations & $\begin{array}{l}\text { AFC, CAF, CONCACAF, CONMEBOL, FIFA, OFC, } \\
\text { UEFA. }\end{array}$ \\
\hline Top domestic leagues & Bundesliga, EPL, LaLiga, Ligue 1, Seria A. \\
\hline $\begin{array}{l}\text { Top International Competitions (among } \\
\text { clubs) }\end{array}$ & Club World Cup, Copa Libertadores, UCL, UEL. \\
\hline Top clubs & $\begin{array}{l}\text { Barcelona FC, FC Bayern Munich, Manchester City, } \\
\text { Manchester United FC, Real Madrid CF. }\end{array}$ \\
\hline $\begin{array}{l}\text { Top International Competitions (among } \\
\text { national teams) }\end{array}$ & $\begin{array}{l}\text { Africa Cup of Nations, Asian Cup, Copa America, FIFA } \\
\text { World Cup, UEFA Euro. }\end{array}$ \\
\hline Top national teams & $\begin{array}{l}\text { Argentine, Brazil, England, France, Germany, Italy, } \\
\text { Mexico, Portugal, Spain. }\end{array}$ \\
\hline Top football kit brands & $\begin{array}{l}\text { Adidas, Joma, Kappa, New Balance, Nike, Puma, } \\
\text { Umbro. }\end{array}$ \\
\hline Top Sponsors (of clubs) & $\begin{array}{l}\text { Accor, AIA, Emirate, Ethihad, Rakuten, Teamviewer, } \\
\text { Three, T-Mobile. }\end{array}$ \\
\hline Top Football manufacturer countries & China, India, Pakistan, Thailand. \\
\hline
\end{tabular}

Knowing the role of the football industry in the international economy helps to understand the importance of international trade and sports. Football also encourages society to respect each other and stand against racism. It allows fans from different backgrounds to support whichever team or player they like. It also helps them forget their professional, domestic and financial woes while diverting their attention to a sport full of entertainment and excitement. Also, by following and learning from their favorite football players, fans can boost their sportsman spirit in their day-today affairs and can strive to live a healthy and active life. Furthermore, football is a great advertising field where some of the biggest international organizations invest in football or sponsor the tournaments. It must be a great opportunity and challenge to be chosen as the official camera brand for filming the World Cup. Isn't it? By making football stars, their brand ambassadors, organizations can sell their products and communicate with the football fans they see as their potential customers and source of revenue. Since not all nations can win football tournaments, nations can strive to benefit from the sports industry in different ways. Countries can benefit from the football industry through manufacturing, selling, and exporting activities.

In this preliminary study, written in a bit informal tone, the general scale of the football industry structure is studied. In the future, more serious and professional attempts can be made to explore the different dimensions highlighted in the current work. The study observed that despite the football associations releasing annual reports, the data from clubs and sponsoring brands is less open. It was also observed that the 2018 World Cup had quite more information than the previous ones. Thus, it is hoped that with time as information becomes more accessible, a better understanding of football's role in business and socio-economic development can be reported.

\section{Appendix - I: Nomenclature}

Abbreviation
AFC
CAF
CBF
CF
CONCACAF
CONMEBOL
DFL
ENG
EPL
ESP
EUR
FAP
FC
FIFA
GDP
GER
OFC
PKR

Full form

Asian Football Confederation

Confederation of African Football

Brazilian Football Confederation

Club de Fútbol

The Confederation of North, Central America and Caribbean Association Football

Confederación Sudamericana de Fútbol

Deutsche Fußball Liga

England

English Premier League

Espana

Euro

Financial Assistance Programme

Football clubs

Fédération Internationale de Football Association

Gross domestic product

Germany

Oceania Football Confederation

Pakistani rupee 


\begin{tabular}{l|l} 
PSG & Paris Saint-Germain \\
UCL & UEFA Champions League \\
UEL & UEFA Europa League \\
UEFA & Union of European Football Associations \\
US & United States \\
USD & United States Dollar
\end{tabular}

\section{References}

Akerman, N. (2015). Bayern Munich, Adidas Agree to New '£650M' Kit Deal: Full Details and Comments, Bleacher Report, Retrieved from https://bleacherreport.com/articles/2447047-bayern-munich-adidas-agree-to-new-650m-kitdeal-full-details-and-comments

Ashby, K. (2014, May 28). Worldwide reach of the Lisbon Final 2014, UEFA, Retrieved from https://www.uefa.com/uefachampionsleague/news/0250-0c510b7eb8f9-fbe1a8bb6fc2-1000--worldwidereach-of-the-lisbon-final/?referrer $=\% 2$ Fuefachampionsleague $\% 2$ Fnews $\% 2$ Fnewsid $\% 3 \mathrm{D} 2111684$

BBC (2019). Manchester City replaces Nike with Puma in kit deal. BBC News, Retrieved from https://www.bbc.com/news/business-47402439

BBC (2021), History of the BBC, BBC, Retrieved from https://www.bbc.com/historyofthebbc/timelines/

BBC (2016, February 26). FIFA presidential election: Gianni Infantino succeeds Sepp Blatter. BBC, Retrieved from https://www.bbc.com/sport/football/35673743

Bob, U. \& Potgieter, C. (2013). Mega-events and Tourism Impacts: Foreign Visitor Perceptions of the 2010 FIFA World Cup in South Africa. Journal of Human Ecology. 43. 71-82. DOI: 10.1080/09709274.2013.11906613.

Cambridge Dictionary (2021). Definition of the transfer fee from the Cambridge Advanced Learner's Dictionary \& Thesaurus, Retrieved from https://dictionary.cambridge.org/dictionary/english/transfer-fee

Cooper, H. and Molloy, C. (2020, December 29). Almost 70\% of the world's soccer balls are made in one city in Pakistan - bere's what it's like inside one of the factories, Business Insider, Retrieved from https://www.businessinsider.com/sialkotpakistan-soccer-ball-factory-bola-gema-2020-12

Deloitte (2020). Annual Review of Football Finance 2020, Deloitte, https://www2.deloitte.com/content/dam/Deloitte/uk/Documents/sports-business-group/deloitte-uk-annualreview-of-football-finance-2020.pdf

Duerden, J. (2019, March 9). Can European footballclubs' claims about Asian fanbases be believed? , The Guardian, Retrieved from https://www.theguardian.com/football/2019/mar/09/european-clubs-asian-fans-premier-leaguevillarreal-china

Eurostat (2021). International trade in sporting goods. Eurostat, Retrieved from https://ec.europa.eu/eurostat/statisticsexplained/index.php?title=International_trade_in_sporting_goods

FIFA (2001, April 03). Article FIFA Survey, approximately 250 million footballers worldwide. FIFA, Retrieved from: https://www.fifa.com/who-we-are/news/fifa-survey-approximately-250-million-footballers-worldwide-88048

FIFA (2011, May 31). FIFA Financial Report 2010. FIFA, Retrieved from https://resources.fifa.com/image/upload/fifafinancial-report-2010-1392046.pdf?cloudid=n4hhe0pvhfdhzxbbbp44

FIFA (2012, May 24). FIF A Financial Report 2011. FIFA, Retrieved from https:// resources.fifa.com/image/upload/fifafinancial-report-2011-1608010.pdf?cloudid=xpxoiqe16w06ngjf67rp.

FIFA (2013a). History of the FIFA World Cup Preliminary Competition (by year). FIFA, Retrieved from https://web.archive.org/web/20131023161459/http://www.fifa.com/mm/document/fifafacts/mencompwc/ 51/97/75/fs-201_19a_fwc-prel-history.pdf

FIFA (2013b). FIFA and Adidas extend partnership until 2030. FIFA, Retrieved from https://www.fifa.com/worldcup/news/fifa-and-adidas-extend-partnership-until-2030-2227271

FIFA (2013c, May 31). FIFA Financial Report 2012, FIFA, Retrieved from https:// resources.fifa.com/image/upload/fifafinancial-report-2012-2039462.pdf?cloudid=kjichsqlvvjr43yyb1au

FIFA (2014, June 10). FIFA Financial Report 2013, FIFA, Retrieved from https:// resources.fifa.com/image/upload/fifafinancial-report-2013-2301207.pdf?cloudid=jjxjmvpbtsxxisqd8acb.

FIFA (2015, May 31). FIFA Financial Report 2014, FIFA, Retrieved from https://img.fifa.com/image/upload/e4e5lkxrbqvgscxgjnhx.pdf

FIFA (2018a). 7.7 Million football fans visit FIFA Fan Fest during Russia 2018, FIFA, https://www.fifa.com/worldcup/news/7-7-million-football-fans-visit-fifa-fan-fest-during-russia-2018

FIFA (2018b, June 13). Canada, Mexico and USA selected as hosts of the 2026 FIFA World Cup ${ }^{\mathrm{TM}}$, FIFA, Retrieved from https://www.fifa.com/worldcup/fifaworldcup2026/news/canada-mexico-and-usa-selected-as-hosts-of-the2026-fifa-world-cuptm

FIFA (2018c). More than half the world watched record-breaking 2018 World Cup. FIFA, Retrieved from https://www.fifa.com/worldcup/news/more-than-half-the-world-watched-record-breaking-2018-world-cup

FIFA (2019, May 15). FIF A Financial Report 2018, FIFA, Retrieved from https://resources.fifa.com/image/upload/fifafinancial-report-2018.pdf?cloudid=xzshsoe2ayttyquuxhq0

FIFA (2020, September 18). FIFA Annual Report 2019, FIFA, Retrieved from https://img.fifa.com/image/upload/ksndm8om7duu5h8qxlpn.pdf

FIFA (2021a). 2018 FIFA World Cup Russia Awards, FIFA, Retrieved from https://www.fifa.com/worldcup/archive/russia2018/awards/ 
FIFA (2021b). FIFA sponsorship and partner Adidas, FIFA, Retrieved from https://www.fifa.com/what-wedo/marketing/sponsorship/partners/adidas

FIFA (2021c). FIFA'sMen's ranking by country. FIFA. https://www.fifa.com/fifa-world-ranking/ranking-table/men/

FIFA (2021d, March 19). 2020 financial statements, FIFA, Retrieved from https://digitalhub.fifa.com/m/5e974064dbb24433/original/FIFA_2020-financial-statements.pdf

FIFA (2021e). FIFA World Cup Timeline, Retrieved from https://www.fifa.com/worldcup/

FIFA (2021f). Member associations of FIFA, FIFA, retrieved from https://www.fifa.com/associations/

FIFA (2021g). Official balls of the FIFA World Cup, FIFA, Retrieved from https://www.fifa.com/worldcup/photos/galleries/alle-spielballe-1143504\#telstar-official-match-ball-the-1970fifa-world-cuptm-photo-adidas-1143467

Forbes (2021a). Soccer team Valuations, Barcelona. Forbes, Retrieved from https://www.forbes.com/teams/barcelona/?sh=706020d91d9b

Forbes (2021b). Soccer team Valuations, Real Madrid. Forbes, Retrieved from https://www.forbes.com/teams/realmadrid/?sh=6372064c6ed 4

Forbes (2021c). The list of most valuable football clubs by Forbes. Forbes, Retrieved from https://www.forbes.com/soccervaluations/list/\#tab:overall

Fraser, D. (2021). Most lucrative shirt sponsorships in football with Man Utd falling below Real Madrid after £,235m TeamViewer deal. The Sun, Retrieved from https://www.thesun.co.uk/sport/football/14393595/man-utd-fall-lucrative-shirtsponsors-teamviewer/

Gásquez, R., \& Royuela, V. (2014). Is Football an Indicator of Development at the International Level?. Social Indicators Research, 117, 827-848 (2014). https://doi.org/10.1007/s11205-013-0368-x

Goal (2021, February 13). Which football teams have the most fans, Goal.com, Retrieved from https://www.goal.com/en/news/which-football-teams-have-most-fans/1qmg4j3457wwh1kxkb7qbdo7qn

Gopinath, G. (2020). The Great Lockdown: Worst Economic Downturn Since the Great Depression, IMF, Retrieved from: https://blogs.imf.org/2020/04/14/the-great-lockdown-worst-economic-downturn-since-the-great-depression/

Guinness World Records. (2021). The Largest attendance at a football match. Guinness World Records, Retrieved from https://www.guinnessworldrecords.com/world-records/64307-largest-attendance-at-a-football-match

Hayward, B. (2017, August 2). Neymar to PSG: How much will he earn, transfer fee, contract length and full Barcelona exit details. Goal.com, Retrieved from https://www.goal.com/en/news/neymar-to-psg-how-much-will-he-earn-transferfee-contract-length-/cosb1yh848ew1ergqy3zy562d

Horky, T. (2020). No sports, no spectators - no media, no money? The importance of spectators and broadcasting for professional sports during COVID-19, Soccer \& Society. https://doi.org/10.1080/14660970.2020.1790358

Javed, S.A., Bo, Y., Tao, L., \& Dong, W. (2021). The 'Dual Circulation' Development Model of China: Background and Insights. Rajagiri Management Journal. https://doi.org/10.1108/RAMJ-03-2021-0016

Johnson, J. (2019). PSG seal record €80m peryear Nike kit deal. ESPN, Retrieved from https://www.espn.com/soccer/parissaint-germain/story/3887581/psg-seal-record-80m-per-year-nike-kit-deal

Khan, H. (2020). Pakistan is the largest exporter of footballs but the game struggles for popularity within its borders. Sport360, Retrieved from https://sport360.com/article/football/343709/pakistan-is-the-largest-exporter-of-footballs-but-thegame-struggles-for-popularity-within-its-borders

Lanfranchi, P., \& Taylor, M. (2001). Moving with the Ball: The Migration of Professional Footballers. Retrieved from https://doi.org/10.5860/choice.39-4035

Lange, D. (2020). A number of foreign owners of top division football clubs in Europe in 2018, by origin. Statista, Retrieved from https://www.statista.com/statistics/894012/foreign-ownership-of-football-clubs-europe-by-origin/

Manzenreiter, W. \& Horne, J. (2018). The Palgrave International Handbook of Football and Politics, 639. https://doi.org/10.1007/978-3-319-78777-0_32

Mendoza, R.G. (2017). Football and economy relations at the international level. Universitat de Barcelona, Retrieved from https://www.ub.edu/school-economics/recent_thesis/football-economy-relations-international-level/

Metro (2020).Liverpool's new Nike kit deal could be record-breaking and worth triple what New Balance brought in. Metro, Retrieved from https://metro.co.uk/2020/01/09/liverpools-new-nike-kit-deal-record-breaking-worth-triple-newbalance-brought-12033419/

Meurer, R., \& Lins, H. N. (2017). The effects of the 2014 World Cup and the 2016 Olympic Games on Brazilian international travel receipts. Tourism Economics, 24(4), 486-491. doi:10.1177/1354816617746261

Naz, F., \& Bögenhold, D. (2020). Understanding labour processes in global production networks: a case study of the football industry in Pakistan. Globalizations, 1-18. doi:10.1080/14747731.2019.1708658

Onwumechili, C., \& Bedeau, K. (2016). Analysis of FIFA's Attempt at Image Repair. Communication \& Sport, 5(4), 407-427. doi:10.1177/2167479516633843

Ozanian, B. (2021). TheWorld's Most V aluable Soccer Teams: Barcelona Edges Real Madrid To Land At No. 1 For First Time. Forbes. Retrieved from https://www.forbes.com/sites/mikeozanian/2021/04/12/the-worlds-most-valuablesoccer-teams-barcelona-on-top-at-48-billion/?sh=70ab673116ac

Premier League (2019a). Premier League 2018/2019 season, match week 38 table. Premier League, Retrieved from https://www.premierleague.com/matchweek/3297/table

Premier League (2019b). Premier League value of central payments to clubs 2018/19, Premier League, Retrieved from https://www.premierleague.com/news/1225126 
Premier League (2021a). Solidarity- What the Premier League does. Premier League, Retrieved from https://www.premierleague.com/about/solidarity

Premier League (2021b). Economic Impact. Premier League, Retrieved from https://www.premierleague.com/this-is$\mathrm{pl} /$ the-premier-league/ 686502

Reuters (2015, June 10). Dutch FA reviening 1996 sponsorship deal with Nike, Reuters, Retrieved from https://www.reuters.com/article/soccer-fifa-netherlands/dutch-fa-reviewing-1996-sponsorship-deal-with-nikeidINKBN0OQ1HQ20150610

Reuters (2018). Arsenal sign new kit deal with Adidas, Reuters, Retrieved from https://www.reuters.com/article/uk-soccerengland-ars-adidas-idUKKCN1MI11R

Reuters (2019a). Adidas extends sponsorship of Real Madrid until 2028, Reuters, Retrieved from https://www.reuters.com/article/adidas-realmadrid-idINL5N22K7UZ

Reuters (2019b). Factbox: Ownership of leading European soccer clubs, Reuters, Retrieved from https://www.reuters.com/article/us-soccer-italy-as-roma-ownership-factbo-idUSKBN1YY0M8

Sabanoglu, T. (2021). Global revenue of Adidas, Nike and Puma from 2006 to 2020, Statista.com, Retrieved from https://www.statista.com/statistics/269599/net-sales-of-adidas-and-puma-worldwide/

Shergold, A. (2018). Jwentus agree new deal with kit makers Adidas worth f.46m-a-season over eight years from 2019 as promotional video features Paul Pogba celebration. Daily Mail, Retrieved from https://www.dailymail.co.uk/sport/football/article6521097/Juventus-agree-new-deal-kit-makers-Adidas-worth-46m-season.html

Simon, G., Tom, B., \& Paul, S. (2019). The FIFA. In: Routledge Handbook of Football Business and Management. ISBN 9780367732462.

Skysports (2016). Barcelona confirm record kit deal with Nike, Sky Sports, Retrieved from https://www.skysports.com/football/news/11833/10637904/barcelona-confirm-record-kit-deal-with-nike

Statista (2020). Number of football jerseys sold worldwide in 2018/2019, by team, Statista, Retrieved from https://www.statista.com/statistics/1118294/football-shirt-sales-by-club/

Tanveer, M., Rizvi, S., \& Riaz, W. (2012). Declining market share of Pakistan in football industry. Asian Journal of Business and management, $1, \quad 33-42$ Retrieved from https://www.academia.edu/3320150/Declining_Market_Share_of_Pakistan_in_Football_Industry

TransferMarkt (2021a). FC Barcelona Cup History, TransferMarkt, Retrieved from https://www.transfermarkt.com/fcbarcelona/pokalhistorie/verein/131

TransferMarkt (2021b). Real Madrid CF Cup History, TransferMarkt, Retrieved from https://www.transfermarkt.com/real-madrid/pokalhistorie/verein/418

UEFA (2012). UEFA Financial Report 2010/11, UEFA. Retrieved from: https://editorial.uefa.com/resources/01fb0f8427c6b6d1-88b2906473d7-1000/2010_11_uefa_financial_report.pdf

UEFA (2013). UEFA Financial Report 2011/12, UEFA. Retrieved from: https://editorial.uefa.com/resources/02090f842880392a-443b7b0c4912-1000/2011_12_uefa_financial_report.pdf

UEFA (2014). UEFA Financial Report 2012/13, UEFA. Retrieved from: https://editorial.uefa.com/resources/02130f84291f5842-9d380fbc43b1-1000/2012_13_uefa_financial_report.pdf

UEFA (2015). UEFA Financial Report 2013/14, UEFA. Retrieved from: https://editorial.uefa.com/resources/021f0f842a4fd845-c75e4279ec1b-1000/2013_14_uefa_financial_report.pdf

UEFA (2016). UEFA Financial Report 2014/15, UEFA. Retrieved from: https://editorial.uefa.com/resources/022a0f842b4cdb03-aae56cb6f120-1000/2014_15_uefa_financial_report.pdf

UEFA (2017). UEFA Financial Report 2015/16, UEFA. Retrieved from: https://editorial.uefa.com/resources/02380f842c842efc-3e95e7aaf3d9-1000/2015_16_uefa_financial_report.pdf

UEFA (2018a). UEFA Financial Report 2016/17, UEFA. Retrieved from: https://editorial.uefa.com/resources/02420f842d5e003a-4e3672bf50c5-1000/2016_17_uefa_financial_report.pdf

UEFA (2018b). UEFA Financial Report 2017/18, UEFA. Retrieved from: https://editorial.uefa.com/resources/024e0f842e7cd20b-39675a5dd261-1000/2017_18_uefa_financial_report.pdf

UEFA (2019). UEFA Financial Report 2018/19, UEFA. Retrieved from: https://editorial.uefa.com/resources/025a0f8430656913-10ccbab24e1d-1000/2018_19_uefa_financial_report.pdf

UEFA (2021a). Champions League History, UEFA. Retrieved from: https:/ /www.uefa.com/uefachampionsleague/history/

UEFA (2021b). President \& Executive Committee annual reports, UEFA. Retrieved from: https://www.uefa.com/insideuefa/documentlibrary/about-uefa/presidentexcoreports/

UEFA (2021c). The UEFA return to play protocol, UEFA. Retrieved from https://www.uefa.com/insideuefa/aboutuefa/news/0265-114289c53314-947427af4d25-1000--the-uefa-return-to-play-protocol/?iv=true

Vierhaus, C. (2018). The international tourism effect of hosting the Olympic Games and the FIFA World Cup. Tourism Economics,135481661881432. https://doi.org/10.1177/1354816618814329

Wilson, B. (2014). Manchester United and Adidas in $6750 \mathrm{~m}$ deal over 10 years, BBC News, Retrieved from https://www.bbc.com/news/business-28282444

Wilson, B. (2016). Chelsea signs record-breaking £.900m Nike kit deal, BBC News, Retrieved from https://www.bbc.com/news/business-37652612

World Bank (2021). GDP current (US\$), All countries and Economies, World Bank, Retrieved from https://data.worldbank.org/indicator/NY.GDP.MKTP.CD?most_recent_value_desc=false

Youtube (2021). FC Barcelona, Channels. Youtube, https://www.youtube.com/c/FCBarcelona/channels 